\title{
Harmonisasi Undang-undang Nomor 11 Tahun 2010 Tentang Cagar Budaya dan Undang-undang Nomor 19 Tahun 2002 Tentang Hak Cipta dalam Pelindungan Arsitektural Bangunan Cagar Budaya
}

\author{
Sri Sularsih \\ Balai Konservasi Borobudur \\ Email : ash_elina87@yahoo.co.id
}

\begin{abstract}
Absrtak: Indonesia memiliki banyak bangunan cagar budaya bergaya arsitektur kolonial yang dibangun pada masa penjajahan Belanda. Periode masa Hindia Belanda itulah yang membedakan antara gaya bangunan masa kolonial dengan bangunan yang lain. Dimulai dari Bangunan Cagar Budaya yang bergaya arsitektur Hindis, bahkan yang merupakan perpaduan dari gaya bangunan Hindis dan tradisional.

Dalam pelaksanaan pelindungan maupun pengembangan Bangunan Cagar Budaya (penelitian, revitalisasi, adaptasi) harus sesuai dengan peraturan perundang-undangan yang berlaku diantaranya adalah Undang-undang Nomor 11 Tahun 2010 tentang Cagar Budaya dan Undang-undang Nomor 19 Tahun 2002 tentang Hak Cipta maupun peraturan perundang-undangan lainnya.

Sekarang ini telah banyak kegiatan pengembangan yang tidak berdasarkan peraturan perundang-undangan sehingga dalam pelaksanaannya dilakukan secara sembarangan sehingga menghilangkan nilai keaslian (orisinalitas) karya cipta arsitektur Bangunan Cagar Budaya. Dalam rangka mempertahankan gaya kearsitekturan Bangunan Cagar Budaya dan keasliannya maka selama kegiatan pelindungan dan pengembangan tidak terlepas dari pengawasan dan pemantauan oleh pemerintah agar sesuai dengan peraturan perundang-undangan yang berlaku. Dengan peran serta pemerintah dan masyarakat dalam "mengawal" kegiatan tersebut, maka keaslian Bangunan Cagar Budaya telah dijaga dan dipertahankan sesuai dengan Undang-undang Nomor 19 Tahun 2002 tentang Hak Cipta dan Undang-undang Nomor 11 Tahun 2010 tentang Cagar Budaya.
\end{abstract}

Kata kunci : Harmonisasi undang-undang, pelindungan, bangunan cagar budaya

\begin{abstract}
Indonesia has many colonial heritage buildings built in the occupation of Dutch East Indies. This period has differentiated the style from one building to another, started from pure Indies architecture, even mix between traditional and Indies style.

In the implementation of protection and development of Cultural Heritage Building (research, revitalization, adaptation) should be in accordance with Law Number 11 Year 2010 regarding and Law Number 19 Year 2002 regarding Copyright as well as other laws.

Nowadays many developments are performed not in accordance with the laws so that the execution has been done uncontrolled and loosen its authenticity of architectural copyright for Cultural Heritage Building. In maintaining architectural style of Cultural Heritage Building and its authenticity, protection and development cannot be separated from the monitoring and surveillance by the government to be in accordance with present regulations. Participation of community and government in "monitoring" those activities means that they also participate in maintaining the authenticity of Cultural Heritage Building based on Law Number 19 Year 2002 regarding copyright and Law Number 11 Year 2010 regarding Cultural Heritage.
\end{abstract}

Keywords: Laws harmonization, protection, cultural heritage building

\section{A. PENGANTAR}

Di Indonesia terdapat banyak bangunan kolonial peninggalan zaman penjajahan yang berusia ratusan tahun. Sampai saat ini, bangunan-bangunan tersebut lebih dikenal dengan Bangunan Cagar Budaya. Menurut Undang-undang Nomor 11 Tahun 2010 tentang Cagar Budaya (selanjutnya disingkat UUCB), "Bangunan Cagar Budaya adalah susunan binaan yang terbuat dari benda alam atau benda buatan manusia untuk memenuhi kebutuhan ruang berdinding dan/atau tidak berdinding, dan beratap". Jika tidak memiliki atap, maka susunan binaan tersebut termasuk Struktur Cagar Budaya seperti yang diamanatkan Pasal 1 butir 4 UUCB.

Suatu bangunan disebut sebagai Bangunan Cagar Budaya apabila memenuhi kriteria cagar budaya berdasarkan Pasal 5 UUCB sebagai berikut: 
1. Berusia 50 (lima puluh) tahun atau lebih;

2. Mewakili massa gaya paling singkat berusia 50 (lima puluh) tahun;

3. Memiliki arti khusus bagi sejarah, ilmu pengetahuan, pendidikan, agama, dan/atau kebudayaan; dan

4. Memiliki nilai budaya bagi penguatan kepribadian bangsa; dan/atau

5. Berupa bangunan yang berunsur tunggal atau banyak, dapat pula berdiri bebas atau menyatu dengan formasi alam (Pasal 7).

Bangunan Cagar Budaya memiliki kategorikategori tertentu seperti yang telah diatur dalam Undangundang Nomor 28 Tahun 2002 tentang Bangunan Gedung, Pasal 84 ayat (1) yang memberikan klasifikasi bangunan gedung dan lingkungannya sebagaimana dimaksud, terdiri atas :

1. Klasifikasi utama diperuntukkan bagi bangunan gedung dan lingkungannya yang secara fisik bentuk aslinya sama sekali tidak boleh diubah;

2. Klasifikasi madya diperuntukkan bagi bangunan gedung dan lingkungannya yang secara fisik bentuk asli eksteriornya sama sekali tidak boleh diubah, namun tata ruang-dalamnya dapat diubah sebagian dengan tidak mengurangi nilai-nilai perlindungan dan pelestariannya;

3. Klasifikasi pratama diperuntukkan bagi bangunan gedung dan lingkungannya yang secara fisik bentuk aslinya dapat diubah sebagian dengan tidak mengurangi nilai-nilai perlindungan dan pelestariannya serta dengan tidak menghilangkan bagian utama bangunan gedung tersebut.

Begitupun dengan Peraturan Pemerintah Nomor 36 Tahun 2005 tentang Peraturan Pelaksanaan Undangundang Nomor 28 Tahun 2002 tentang Bangunan Gedung. Kategori bangunan itulah yang digunakan sebagai dasar dalam melakukan kegiatan pelindungan dan pengembangan Bangunan Cagar Budaya.

Pelindungan yang dimaksud adalah upaya mencegah dan menanggulangi dari kerusakan, kehancuran, atau kemusnahan dengan cara Penyelamatan, Pengamanan, Zonasi, Pemeliharaan, dan Pemugaran Cagar Budaya. Maraknya kasus pembongkaran bangunan cagar budaya beberapa tahun terakhir sangatlah disayangkan oleh para pemerhati pelestarian cagar budaya yang ada di Indonesia. Bermacam-macam alasan yang digunakan untuk membenarkan tindakan tersebut. Kebutuhan perekonomian hidup yang semakin mendesak, kondisi bangunan yang sudah tidak layak lagi, bahkan dikarenakan modernisasi yang "menggiurkan" bagi pemilik maupun pihak berkepentingan di dalamnya menjadi faktor yang kuat agar bangunan tersebut dirubuhkan untuk dibangun kembali dengan bangunan modern. Seperti yang pernah terjadi tahun lalu yaitu kasus Rumah Cantik yang berada di Jl. Teuku Cik Di Tiro, Menteng, Jakarta Pusat yang termasuk salah satu rumah yang terdaftar sebagai cagar budaya karena masih menggunakan arsitektur masa kolonial Belanda namun dibongkar oleh pemilik barunya.

Bangunan Cagar Budaya memiliki gaya arsitektur yang berbeda antara satu bangunan dengan bangunan yang lain. Arsitektur inilah yang mengandung nilai, karakter, dan ciri khas bangunan, dimana gaya bangunan antara masa yang satu dengan masa yang lain berbeda. Sebagai contoh, arsitektur bangunan kolonial yang sebagian besar adalah bangunannya tinggi, kokoh, dan beratap datar, sedangkan untuk rumah tempat tinggal atapnya berbentuk joglo atau limasan. Bangunan kolonial zaman Hindia Belanda sekarang ini disebut dengan Bangunan Indis yang merupakan perpaduan ciri bangunan tradisional dengan ciri bangunan Belanda.

Arsitektur suatu bangunan termasuk ciptaan dalam bidang ilmu pengetahuan, seni, dan sastra yang dilindungi oleh Pasal 12 Undang-undang Nomor 19 Tahun 2002 tentang Hak Cipta (selanjutnya disingkat UUHC). Budi Agus Riswandi menyatakan bahwa suatu ciptaan harus mempunyai keaslian untuk dapat menikmati hak-hak yang diberikan undang-undang keaslian, sangat erat hubungannya dengan bentuk perwujudan suatu ciptaan. Keaslian arsitektur Bangunan Cagar Budaya terwujud dalam model atau bentuk bangunan yang mempunyai karakter atau ciri khas masa dibangunnya Bangunan Cagar Budaya (Budi Agus Riswandi: 2005).

Hak cipta itu sendiri merupakan hak eksklusif bagi Pencipta atau Pemegang Hak Cipta untuk mengumumkan atau memperbanyak ciptaannya, yang timbul secara otomatis setelah suatu ciptaan dilahirkan tanpa mengurangi pembatasan menurut peraturan perundangundangan yang berlaku. Pengertian tersebut tercantum dalam Pasal 1 butir 1 UUHC, maka dapat dikatakan bahwa tanpa dilakukan pendaftaran pun sebenarnya hak cipta suatu ciptaan tersebut sudah memperoleh perlindungan hukum. Hanya saja terdapat kelemahan jika hak cipta tersebut tidak didaftarkan secara administrasi, jika terjadi sengketa maka sulit dalam proses pembuktiann di pengadilan.

Telah diamatkan dalam UUHC bahwa pemegang Hak Cipta atas karya peninggalan prasejarah, sejarah, dan benda budaya nasional lainnya adalah negara. Oleh sebab itu, jika dilaksanakan suatu perubahan dan/atau pengalihfungsian terhadap bangunan kolonial, rumah adat, atau bangunan lain yang memiliki ciri khas arsitektur tertentu harus memperoleh ijin dari negara. Negara dalam 
hal ini adalah pemerintah dan/atau pemerintah daerah berdasar peringkat Bangunan Cagar Budaya dengan tetap mempertahankan keaslian atau ciri khas gaya arsitektur bangunan. Pemberian ijin dimaksudkan untuk meminimalisir dan mencegah terjadinya kesewenangwenangan dalam pelindungan, pengembangan, dan pemanfaatan Bangunan Cagar Budaya.

B. Harmonisasi Undang-undang Nomor 11 tahun 2010 tentang Cagar Budaya dan Undang-undang Nomor 19 Tahun 2002 tentang Hak Cipta dalam Pelindungan Arsitektural Bangunan Cagar Budaya

Dewasa ini banyak kegiatan pengalihfungsian Bangunan Cagar Budaya melalui pembongkaran demi meningkatkan potensi maupun daya tariknya, bahkan sampai menimbulkan pro kontra di kalangan masyarakat karena telah melanggar peraturan perundang-undangan yang berlaku (dalam hal ini adalah Undang-undang Nomor 11 Tahun 2010 tentang Cagar Budaya). Bangunan Cagar Budaya merupakan karya cipta sang pencipta pada masanya dan bercirikan gaya arsitektur bangunan saat itu yang wajib dilindungi demi kelestariannya.

Bangunan Cagar Budaya yang dimiliki oleh perseorangan tidaklah sebanyak dengan Bangunan Cagar Budaya yang tidak diketahui kepemilikkannya, sehingga kepemilikan Bangunan Cagar Budaya tersebut dikuasai oleh negara (Pasal 15 UUCB). Pasal 10 UUHC menyatakan bahwa Negara memegang Hak Cipta atas karya peninggalan prasejarah, sejarah, dan benda budaya nasional lainnya. Berdasarkan pasal tersebut telah jelas dinyatakan bahwa Hak Cipta peninggalan budaya yang memiliki arti penting bagi karakter bangsa dipegang dan dikuasai oleh Negara, termasuk Bangunan Cagar Budaya. Hal ini diperjelas dengan Pasal 12 ayat (1) huruf g UUHC yang menyatakan bahwa salah satu karya intelektual hak cipta yang dilindungi adalah karya arsitektur, yang meliputi seni gambar bangunan, seni gambar miniatur, dan seni gambar maket bangunan. Karya arsitektur Bangunan Cagar Budaya dilindungi oleh negara, oleh sebab itu dalam melakukan pelestarian suatu Bangunan Cagar Budaya wajib mendapat ijin Negara selaku pemegang hak cipta dan demi melindungi obyek ciptaan itu sendiri.

Tabel 1.Pelindungan Arsitektural Bangunan Cagar Budaya berdasar Undang-undang Nomor 11 tahun 2010 tentang Cagar Budaya dan Undang-undang Nomor 19 Tahun 2002 tentang Hak Cipta

\section{Undang-undang Nomor 11 tahun 2010 tentang Cagar Budaya}

\section{Pasal 1}

Bangunan Cagar Budaya adalah susunan binaan yang terbuat dari benda alam atau benda buatan manusia untuk memenuhi kebutuhan ruang berdinding dan/atau tidak berdinding, dan beratap
Undang-undang Nomor 19 Tahun 2002 tentang Hak Cipta

Pasal 2 ayat (1)

Hak cipta merupakan hak eksklusif bagi Pencipta atau Pemegang Hak Cipta untuk mengumumkan atau memperbanyak ciptaannya, yang timbul secara otomatis setelah suatu ciptaan dilahirkan tanpa mengurangi pembatasan menurut peraturan perundang-undangan yang berlaku

\section{Pasal 10 ayat (1)}

\section{Pasal 1 butir (9)}

Dikuasai oleh Negara adalah kewenangan tertinggi yang dimiliki oleh negara dalam menyelenggarakan pengaturan perbuatan hukum berkenaan dengan pelestarian Cagar Budaya.

Pasal 12 ayat (1)

Setiap orang dapat memiliki dan/atau menguasaiBenda Cagar Budaya, Bangunan Caga r Budaya, Struktur Cagar Budaya, dan/atau Situs Cagar Budaya dengan tetap memperhatikan fungsi sosialnya sepanjang tidak bertentangan dengan ketentuan Undang-Undang ini.

Pasal 15

Cagar Budaya yang tidak diketahui kepemilikannya dikuasai oleh Negara

\section{Pasal 77 ayat (2)}

Pemugaran Cagar Budaya sebagaimana dimaksud pada ayat (1) harus memperhatikan:

a. keaslian bahan, bentuk, tataletak, gaya, dan/atau teknologi pengerjaan;

b. kondisi semula dengan tingkat perubahan sekecil mungkin;

c. penggunaan teknik, metode, dan bahan yang tidak bersifat merusak dan

d. kompetensi pelaksana di bidang pemugaran

Pasal 78 ayat (1)

Pengembangan Cagar Budaya dilakukan dengan memperhatikan prinsip kemanfaatan, keamanan, keterawatan, keaslian, dan nilai-nilai yang melekat padanya.
Negara memegang Hak Cipta atas karya peninggalan prasejarah, sejarah, dan benda budaya nasional lainnya. 
Pasal 80 ayat (1)

Revitalisasi potensi Situs Cagar Budaya atau Kawasan Cagar Budaya memperhatikan tata ruang, tata letak, fungsi sosial, dan/atau lanskap budaya asli berdasarkan kajian

Pasal 83

(1) Bangunan Cagar Budaya atau Struktur Cagar Budaya dapat dilakukan adaptasi untuk memenuhi kebutuhan masa kini dengan tetap mempertahankan:

a. ciri asli dan/atau muka Bangunan Cagar Budaya atau Struktur Cagar Budaya; dan/atau

b. ciri asli lanskap budaya dan/atau permukaan tanah Situs Cagar Budaya atau Kawasan Cagar Budaya sebelum dilakukan adaptasi.

(2) Adaptasi sebagaimana dimaksud pada ayat (1) dilakukan dengan: a.mempertahankan nilai-nilai yang melekat pada Cagar Budaya;

b. menambah fasilitas sesuai dengan kebutuhan;

c. mengubah susunan ruang secara terbatas; dan/atau

d.mempertahankan gaya arsitektur, konstruksi asli, dan keharmonisan estetika lingkungan di sekitarnya.

\section{Pasal 1 butir 14}

Tenaga Ahli Pelestarian adalah orang yang karena kompetensi keahlian

khususnya dan/atau memiliki sertifikat di bidang Pelindungan,

Pengembangan, atau Pemanfaatan Cagar Budaya.

Pasal 53 ayat (2)

Kegiatan Pelestarian Cagar Budaya harus dilaksanakan atau

dikoordinasikan oleh Tenaga Ahli Pelestarian dengan memperhatikan etika pelestarian.

Pasal 66 ayat (1)

Setiap orang dilarang merusak Cagar Budaya, baik seluruh maupun bagian-bagiannya, dari kesatuan, kelompok, dan/atau dari letak asal.

Pasal 105

Setiap orang yang dengan sengaja merusak Cagar Budaya sebagaimana dimaksud dalam Pasal 66 ayat (1) dipidana dengan pidana penjara paling singkat 1 (satu) tahun dan paling lama 15 (lima belas) tahun dan/atau denda paling sedikit Rp500.000.000,00 (lima ratus juta rupiah) dan paling banyak Rp5.000.000.000,00 (lima miliar rupiah).

\section{Pasal 15 butir $\mathrm{f}$}

Dengan syarat bahwa sumbernya harus disebutkan atau dicantumkan, tidak dianggap sebagai pelanggaran Hak Cipta :

f. perubahan yang dilakukan berdasarkan pertimbangan pelaksanaan teknis atas karya arsitetur, seperti ciptaan bangunan

\section{Pasal 72}

Barang siapa dengan sengaja dan tanpa hak melakukan perbuatan sebagaimana dimaksud dalam Pasal 2 ayat (1) atau Pasal 49 ayat (1) dan ayat (2) dipidana dengan pidana penjara paling singkat 1 (satu) bulan dan/atau denda paling sedikit Rp. 1.000.000, - (satu juta rupiah), atau pidana penjara paling lama 7 (tujuh) tahun dan/atau denda paling banyak Rp. 5.000.000.000,- (lima miliar rupiah).
Pelaksanaan pelestarian (pelindungan dan pengembangan) Bangunan Cagar Budaya harus tidak mengubah nilai dan/atau karakter Bangunan Cagar Budaya, yang tercermin dalam keaslian bahan, bentuk, tata letak, gaya, dan/atau teknologi pengerjaan. Gaya yang dimaksud dalah gaya arsitektural bangunan yang harus dilestarikan. Hal inilah yang menjadi prinsip perlindungan hak cipta suatu seni arsitektur Bangunan Cagar Budaya sebagai obyek hak cipta.

Kegiatan pengembangan merupakan suatu kegiatan yang bertujuan untuk meningkatkan potensi nilai, informasi, dan promosi Cagar Budaya serta pemanfaatannya melalui Penelitian, Revitalisasi, dan Adaptasi secara berkelanjutan serta tidak bertentangan dengan tujuan Pelestarian (Pasal 1 butir 29 UUCB). Kegiatan pengembangan tersebut haruslah dilakukan dengan tetap memperhatikan prinsip kemanfaatan, keamanan, keterawatan, keaslian, dan nilai-nilai yang melekat padanya (Pasal 78 UUCB).

Dalam Pasal 1 UUCB dinyatakan bahwa Revitalisasi adalah kegiatan pengembangan yang ditujukan untuk menumbuhkan kembali nilai-nilai penting Cagar Budaya dengan penyesuaian fungsi ruang baru yang tidak bertentangan dengan prinsip pelestarian dan nilai budaya masyarakat, sedangkan adaptasi adalah upaya pengembangan Cagar Budaya untuk kegiatan yang lebih sesuai dengan kebutuhan masa kini dengan melakukan perubahan terbatas yang tidak akan mengakibatkan kemerosotan nilai pentingnya atau kerusakan pada bagian yang mempunyai nilai penting. Revitasasi dan adaptasi yang dilakukan dengan tetap mempertahankan ciri asli dan nilai-nilai yang melekat pada suatu Bangunan Cagar Budaya. Gambar dalam foto 1 dan 2 adalah contoh Bangunan Cagar Budaya yang telah direvitalisasi dan diadaptasi sesuai peraturan perundangundangan yang berlaku.

Bangunan Cagar Budaya perlu dijaga dan dilestarikan karena memiliki arti penting dan menjadi identitas bagi suatu kelompok, daerah, bahkan negara, namun terkadang kenyataan di lapangan berkata lain. Berdasarkan Peraturan Daerah Khusus Ibukota Jakarta Nomor 9 Tahun 1999 tentang Pelestarian dan 


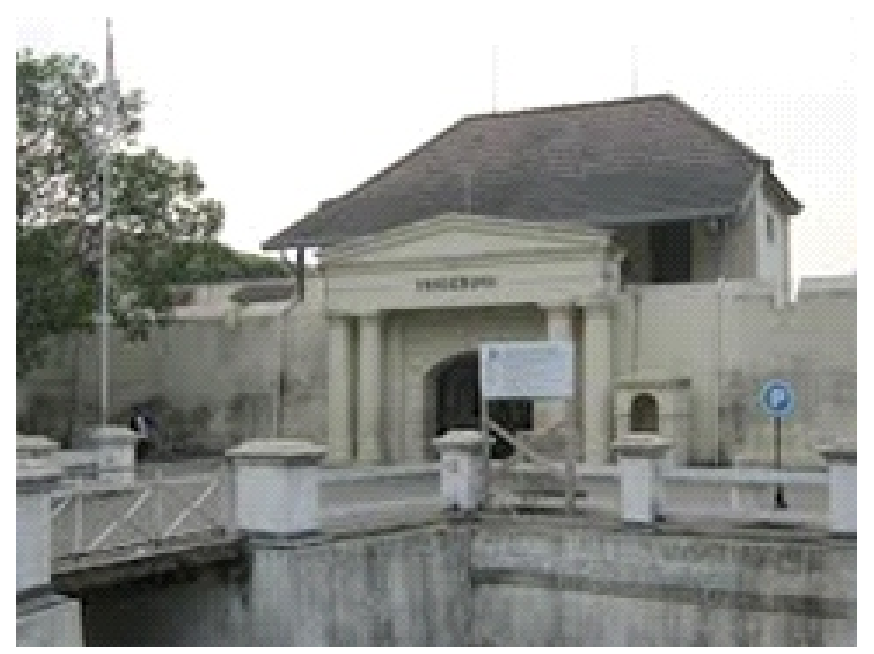

Foto 1. Revitalisasi Benteng Vredeberg (Sumber : google.com)

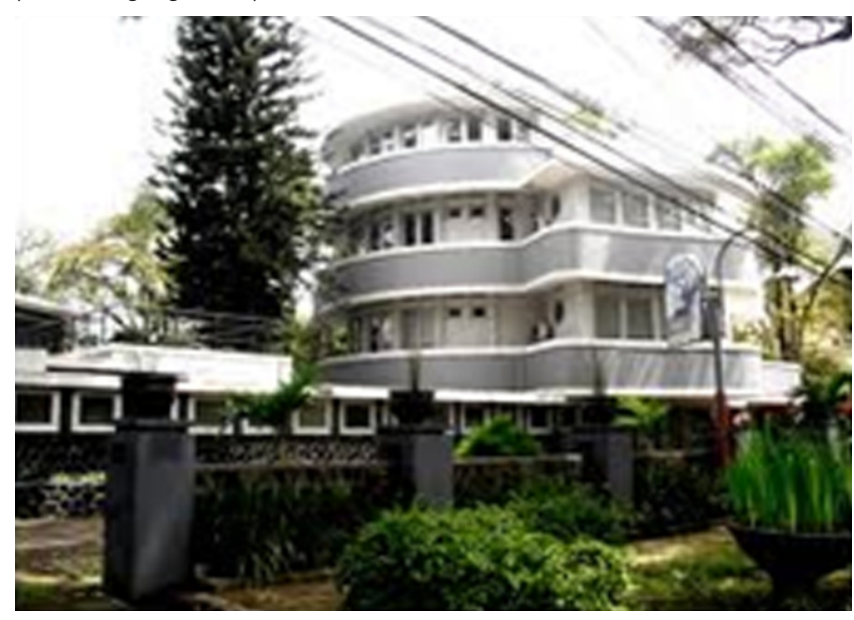

Foto 2. Adaptasi arsitektural Gedung De Drie Kleur untuk Bank BTPN Bandung (Sumber : google.com)

Pemanfaatan lingkungan dan Bangunan Cagar Budaya, bangunan cagar budaya dari segi arsitektur maupun sejarahnya dibagi dalam 3 (tiga) golongan yaitu:

\section{Golongan A}

a. Bangunan dilarang dibongkar dan atau diubah

b. Apabila kondisi fisik bangunan buruk, roboh, terbakar, atau tidak layak tegak dapat dilakukan pembongkaran untuk dibangun kembali sama seperti semula sesuai dengan aslinya.

c. Pemeliharaan dan perawatan bangunan harus menggunakan bahan yang sama/sejenis atau memiliki karakter yang sama, dengan mempertahankan detail ornamen bangunan yang telah ada

d. Dalam upaya revitalisasi memungkinkan adanya penyesuaian/perubahan fungsi sesuai rencana kota yang berlaku tanpa mengubah bentuk bangunan aslinya

e. Di dalam persil atau lahan bangunan cagar budaya memungkinkan adanya bangunan tambahan yang menjadi satu kesatuan yang utuh dengan bangunan utama

\section{Golongan B}

a. Bangunan dilarang dibongkar secara sengaja, dan apabila kondisi fisik bangunan buruk, roboh, terbakar, atau tidak layak tegak dapat dilakukan pembongkaran untuk dibangun kembali sama seperti semula sesuai dengan aslinya

b. Pemeliharan dan perawatan bangunan harus dilakukan tanpa mengubah pola tampak depan, atap, dan warna, serta dengan mempertahankan detail dan ornamen bangunan yang penting.

c. Dalam upaya rehabilitasi dan revitalisasi memungkinkan adanya perubahan tata ruang dalam asalkan tidak mengubah struktur utama bangunan

d. Di dalam persil atau lahan bangunan cagar budaya dimungkinkan adanya bangunan tambahan yang menjadi satu kesatuan yang utuh dengan bangunan utama

\section{Golongan C}

a. Perubahan bangunan dapat dilakukan dengan tetap mempertahankan pola tampak muka, arsitektur utama, dan bentuk atap bangunan

b. Detail ornamen dan bahan bangunan disesuaikan dengan arsitektur bangunan di sekitarnya dalam keserasian lingkungan

c. Penambahan Bangunan di dalam perpetakan atau persil hanya dapat dilakukan di belakang bangunan cagar budaya yang harus sesuai dengan arsitektur bangunan cagar budaya dalam keserasian lingkungan

d. Fungsi bangunan dapat diubah sesuai dengan rencana Kota

(http://abadisantosoganteng.blogspot.com/2011/04/ba ngunan-cagar-budaya.html)

Pada kasus Rumah Cantik misalnya, rumah tersebut memang termasuk dalam Bangunan Cagar Budaya Golongan C, namun bukan berarti dapat dibongkar tanpa mengindahkan aturan yang ada dan menghilangkan keaslian bangunan. Hal tersebut diungkapkan pula oleh Yori Antar, arsitek senior Indonesia (Riana Afifah: 2011).

"Sebenarnya bangunan dengan golongan $\mathrm{C}$ ini dapat diubah sesuka hati, hanya saja ciri bangunan khas kolonial Menteng tidak boleh hilang. Desain bangunan baru pun harus dikonsultasikan terlebih dahulu oleh pihak terkait apakah sudah sesuai atau belum. "Golongan C itu boleh diapakan saja. Tapi, saat dibangun baru, bangunannya tetap harus berciri kolonial. Tidak boleh tiba-tiba pake gaya klasisisme, victorian, atau gaya seperti rumah-rumah di Milan," ujar Yori (Riana Afifah : 2011). 


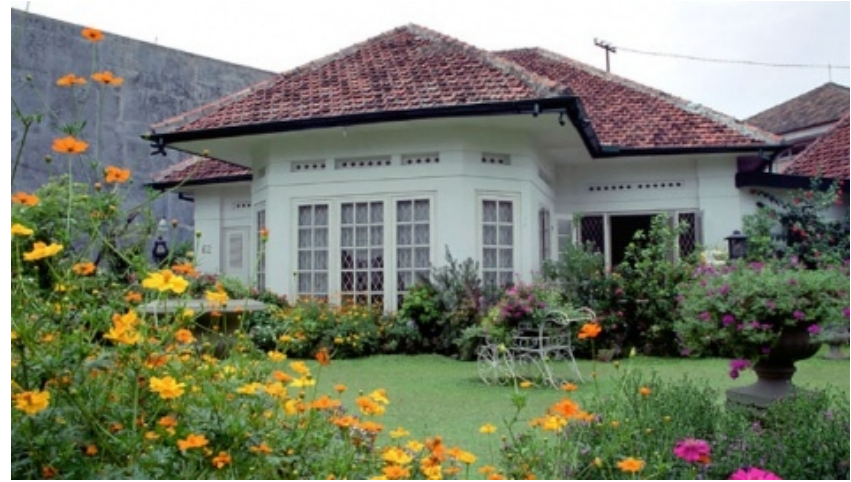

Foto 3. Kondisi awal Rumah Cantik yang sangat menarik

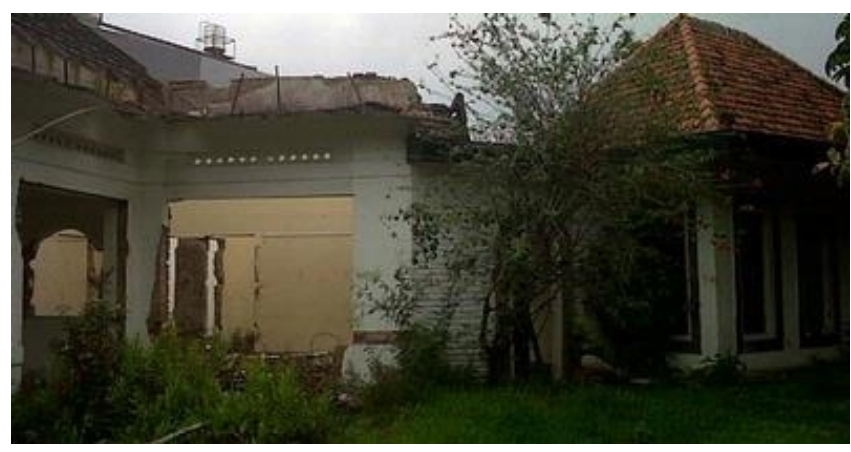

Foto 4. Rumah Cantik di Jalan Cik Dik Tiro No. 62 tampak terbengkalai dan separuh bangunannya sudah dibongkar

Sumber : Kompas.com edisi Jumat, 2 Desember 2011 | 04:09 WIB

Kolam Renang Tirta Merta atau yang lebih dikenal dengan sebutan Kolam Renang Centrum merupakan bangunan yang berusia lebih dari 50 tahun dan termasuk Bangunan Cagar Budaya di Bandung, hanya saja belum diatur lebih lanjut mengenai kategori bangunan tersebut. Kolam renang Centrum dialihfungsikan menjadi sebuah rumah makan, dan hal tersebut diizinkan karena dalam Peraturan Daerah Nomor 19 Tahun 2009 tentang Pengelolaan Kawasan dan Bangunan Cagar Budaya hanya mengatur 99 Bangunan Cagar Budaya yang termasuk dalam Kategori A sehingga hal tersebut melemahkan Bangunan-bangunan Cagar Budaya lain yang kemungkinan memiliki Kategori B dan C. Dalam hal ini, yang menjadi permasalahan adalah lemahnya peraturan perundang-undangan yang tidak mengatur lebih lanjut mengenai kategori Bangunan Cagar Budaya selain yang diatur dalam perda tersebut. Hal ini dapat menjadi celah bagi pihak lain untuk melakukan perubahan dan/atau pengalihfungsian Bangunan Cagar Budaya yang dapat menghilangkan karakteristik arsitektur bangunan.

Beberapa daerah memang telah memiliki kebijakan pelestarian berkaitan dengan pembagian golongan Bangunan Cagar Budaya, misalnya DKI Jakarta dengan Peraturan Daerah Khusus Ibukota Jakarta Nomor 9 Tahun 1999 tentang Pelestarian dan Pemanfaatan Lingkungan dan Bangunan Cagar Budaya dan Bandung dengan Peraturan Daerah Nomor 19 Tahun 2009 tentang Pengelolaan Kawasan dan Bangunan Cagar Budaya.

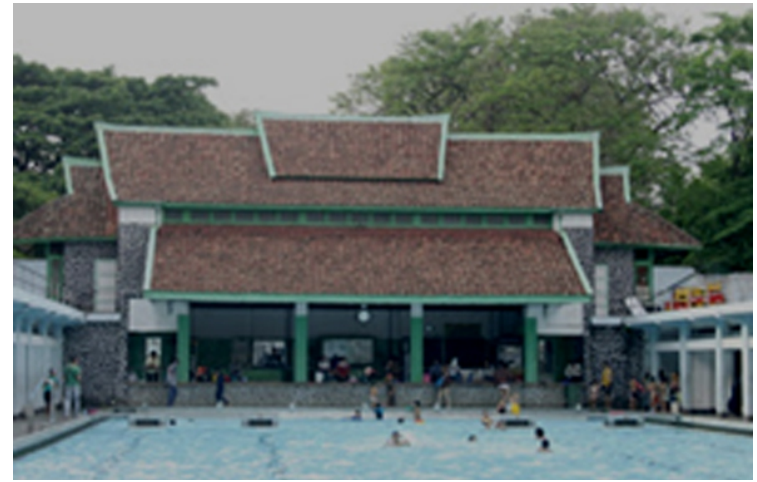

Foto 5. Kolam renang Tirta Merta atau Centrum sebelum dibongkar (Sumber : google. Com)

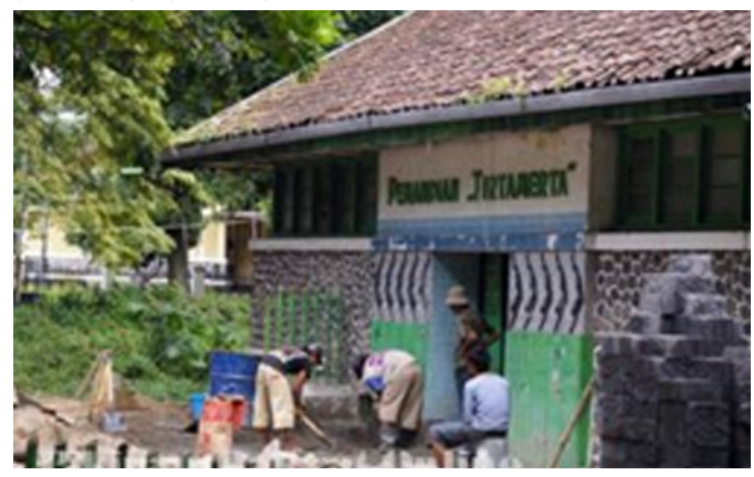

Foto 6. Pembongkaran kolam renang Tirta Merta (Sumber: google. Com)

Daerah-daerah yang belum memiliki kebijakan pelestarian berpedoman pada Peraturan Pemerintah Nomor 36 Tahun 2005 tentang Peraturan Pelaksanaan Undangundang Nomor 28 Tahun 2002 tentang Bangunan Gedung yang masih bersifat umum.

Hal ini sejalan pula dengan Pasal 38 ayat (4) Undang-undang Nomor 28 Tahun 2002 tentang Bangunan Gedung bahwa :

(1) Bangunan gedung dan lingkungannya yang ditetapkan sebagai cagar budaya sesuai dengan peraturan perundang-undangan harus dilindungi dan dilestarikan.

(2) Penetapan bangunan gedung dan lingkungannya yang dilindungi dan dilestarikan sebagaimana dimaksud dalam ayat (1) dilakukan oleh Pemerintah Daerah dan/atau Pemerintah dengan memperhatikan ketentuan perundang-undangan.

(3) Pelaksanaan perbaikan, pemugaran, perlindungan, serta pemeliharaan atas bangunan gedung dan lingkungannya sebagaimana dimaksud dalam ayat (1) hanya dapat dilakukan sepanjang tidak mengubah nilai dan/atau karakter cagar budaya yang dikandungnya.

(4) Perbaikan, pemugaran, dan pemanfaatan bangunan gedung dan lingkungan cagar budaya yang dilakukan menyalahi ketentuan fungsi dan/atau karakter cagar budaya, harus dikembalikan sesuai dengan peraturan perundang-undangan.

(5) Ketentuan mengenai perlindungan dan pelestarian 
sebagaimana dimaksud dalam ayat (1) dan ayat (2) serta teknis pelaksanaan perbaikan, pemugaran dan pemanfaatan sebagaimana dimaksud dalam ayat (3) dan ayat (4) diatur lebih lanjut dengan Peraturan Pemerintah.

Dalam pelaksanaan pengembangan dengan melakukan perubahan dan/atau pengalihfungsian bangunan hanya diijinkan jika berdasarkan pertimbangan pelaksanaan teknis atas karya arsitektur (Pasal 15 huruf $\mathrm{f}$ UUHC). Pertimbangan teknis yang dimaksud adalah persyaratan tata bangunan dan persyaratan keandalan bangunan gedung yang diatur dalam Undang-undang Nomor 28 Tahun 2002 tentang Bangunan Gedung. Pertimbangan teknis tersebut dipergunakan sebagai dasar dilaksanakannya suatu perubahan dan/atau pengalihfungsian bangunan dengan tetap mempertahankan keaslian karakter bangunan. Diatur pula dalam Pasal 53 ayat (2) UUCB bahwa dalam melaksanakan kegiatan pelestarian, termasuk pelindungan dan pengembangan Bangunan Cagar Budaya harus dilaksanakan dan dikoordinasikan dengan Tenaga Ahli Pelestarian serta mempertimbangkan kemungkinan dilakukannya pengembalian kondisi awal seperti sebelum kegiatan pelestarian (melalui pemugaran).

Tenaga Ahli Pelestarian menurut UUCB adalah tenaga yang memiliki kompetensi di bidang pelestarian dan telah bersertifikasi. Untuk sekarang ini, belumlah memenuhi persyaratan yang dimaksud dikarenakan belum dilaksanakannya sertifikasi tenaga-tenaga ahli bidang pelestarian. Tenaga-tenaga ahli yang ada sekarang ini masih berdasarkan kompetensi kerja dan pengalaman yang dimiliki, belum tersertifikasi. Di dalam UUCB, telah diatur mengenai sertifikasi Tenaga Ahli Pelestarian sehingga ke depannya dalam melaksanakan kegiatan pelestarian meliputi pelindungan, pengembangan, dan pemanfaatan harus dilaksanakan oleh pelestari tersertifikasi.

Pada praktek di lapangan, kejadian pembongkaran Bangunan Cagar Budaya yang sembarangan terjadi dikarenakan faktor lemahnya pengawasan selama proses pemugaran atau pengembangan berlangsung. Chanawi dalam bukunya menyatakan bahwa hak cipta adalah suatu hak eksklusif berupa hak yang bersifat istimewa yang semata-mata hanya diperuntukkan bagi pencipta atau pemegang hak cipta sehingga tidak ada pihak lain yang boleh memanfaatkan hak tersebut tanpa izin (Chanawi, H. Adami : 2007). Jika dilaksanakan suatu perubahan dan/atau pengalihfungsian Bangunan Cagar Budaya yang tidak berdasar izin dan/atau pertimbangan teknis maka dapat dikatakan bahwa kegiatan tersebut melanggar ketentuan yang diatur oleh UUHC yaitu melanggar hak eksklusif pemegang hak cipta. Terhadap pelanggaran tersebut, dikenakan Pasal 72 ayat (1) UUHC yaitu diancam pidana penjara paling singkat 1 (satu) bulan dan/atau denda paling sedikit Rp. 1.000.000,--(satu juta rupiah), atau pidana penjara paling lama 7 (tujuh) tahun dan/atau denda paling banyak Rp. 5.000.000.000,-(lima miliar rupiah).

Jika dalam melaksanakan perubahan seperti yang diatur dalam UUHC, dengan tanpa disertai pertimbangan pelaksanaan teknis maka kegiatan tersebut dikatakan melawan hukum dan dapat dikenai ketentuan pidana seperti yang diatur oleh Pasal 105 UUCB yang menyatakan bahwa setiap orang yang dengan sengaja merusak Cagar Budaya sebagaimana dimaksud dalam Pasal 66 ayat (1) dipidana dengan pidana penjara paling singkat 1 (satu) tahun dan paling lama 15 (lima belas) tahun dan/atau denda paling sedikit Rp 500.000.000,00 (lima ratus juta rupiah) dan paling banyak Rp 5.000.000.000,00 (lima miliar rupiah). Pasal 66 ayat (1) menyatakan bahwa setiap orang dilarang merusak Cagar Budaya, baik seluruh maupun bagian-bagiannya, dari kesatuan, kelompok, dan/atau dari letak asal. Ketentuan pidana yang diatur dalam UUHC maupun UUCB dapat menjerat pelaku yang melakukan pembongkaran Bangunan Cagar yang melanggar peraturan perundang-undangan berlaku. Dakwaan yang diajukan dapat bersifat subsidair, jika salah satu dakwaan terbukti maka sudah dapat dikenai pidana. Didasarkan pula pada asas hukum Lex Specialis derogat Lex Generalis maka pelaku dikenai ancaman pidana seperti yang diatur dalam ketentuan UUCB.

\section{Kesimpulan}

Telah ada harmonisasi peraturan perundangundangan dalam pelaksanaan pelestarian Bangunan Cagar Budaya melalui Undang-undang Nomor 11 Tahun 2010 tentang Cagar Budaya dan Undang-undang Nomor 19 Tahun 2002 tentang Hak Cipta, maupun peraturan perundang-undangan lainnya yang mendukung. Dalam melaksanakan kegiatan pelindungan, pengembangan, maupun pemanfaatan Bangunan Cagar Budaya untuk meningkatkan nilai dan potensi haruslah tetap mempertahankan keaslian ciptaan dari Bangunan Cagar Budaya dan setiap bentuk perubahan yang dilakukan harus berdasarkan pertimbangan teknis, tidak boleh tidak. Hal ini dilaksanakan sesuai Undang-undang Nomor 11 Tahun 2010 tentang Cagar Budaya dan Undang-undang Nomor 19 Tahun 2002 tentang Hak Cipta bahwa gaya arsitektur merupakan salah satu keaslian yang harus dipertahankan dan dilindungi. Jika terjadi pelanggaran dan/atau pidana seperti yang diatur dalam pasal peraturan perundang-undangan tersebut, maka dikenai ketentuan pidana sesuai peraturan perundang-undangan berlaku. 
Kasus-kasus pembongkaran Bangunan Cagar Budaya terjadi dikarenakan kurang terkontrolnya pengawasan terhadap pelaksanaan pengembangan Bangunan Cagar Budaya. Harus ada koordinasi bersama antara instansi-instansi yang berwenang di bidang cagar budaya, perizinan pendirian bangunan, dan penataan ruang karena perizinan itulah yang menjadi dasar pelaksanaan pembongkaran dan/atau pengalihfungsian suatu Bangunan Cagar Budaya. Masyarakat belum memahami mengenai konsep pelindungan dan pengembangan Bangunan Cagar Budaya dengan tetap mempertahankan keaslian karya cipta arsitekturnya sehingga diperlukan suatu bentuk sosialisasi kepada masyarakat mengenai Cagar Budaya dan pelestariannya. Masih banyak pula daerah yang belum memiliki kebijakan pelestarian sesuai dengan kondisi daerah masing-masing sehingga masih banyak terjadi kasus-kasus pembongkaran Bangunan Cagar Budaya. Pemerintah Daerah dalam hal ini perlu membuat kebijakan pelestarian yang dituangkan dalam peraturan daerah sesuai kondisi daerah masingmasing.

Pemugaran merupakan salah satu cara dalam mempertahankan karya cipta arsitektur Bangunan Cagar Budaya. Dalam Penjelasan Peraturan Pemerintah
Republik Indonesia Nomor 10 Tahun 1993 tentang Pelaksanaan Undang-undang Nomor 5 Tahun 1992 tentang Benda Cagar Budaya Pasal 27 ayat (2), mengatur mengenai pemugaran. Pemugaran merupakan serangkaian kegiatan yang bertujuan untuk mengembalikan keaslian bentuk benda cagar budaya dan memperkuat strukturnya bila diperlukan, yang dapat dipertanggungjawabkan dari segi arkeologis, historis, dan teknis dalam upaya pelestarian benda cagar budaya, meliputi kegiatan restorasi, rekonstruksi, rehabilitasi, dan konsolidasi. Pada beberapa contoh kasus yang ada, sebenarnya dapat dipugar kembali untuk mengembalikan keaslian sesuai peraturan perundang-undangan yang berlaku. Hal ini berdasarkan pula Pasal 38 ayat (4) Undang-undang Nomor 28 Tahun 2002 tentang Bangunan Gedung yang menyatakan bahwa perbaikan, pemugaran, dan pemanfaatan bangunan gedung dan lingkungan cagar budaya yang dilakukan menyalahi ketentuan fungsi dan/atau karakter cagar budaya, harus dikembalikan sesuai dengan peraturan perundangundangan.

Peraturan Pemerintah Nomor 36 Tahun 2005 tentang Peraturan Pelaksanaan Undang-undang Nomor 28 Tahun 2002 tentang Bangunan Gedung.

Peraturan Daerah Khusus Ibukota Jakarta Nomor 9 Tahun 1999 tentang Pelestarian dan Pemanfaatan Lingkungan dan Bangunan Cagar Budaya

Peraturan Daerah Kota Bandung Nomor 19 Tahun 2009 tentang Pengelolaan Kawasan dan Bangunan Cagar Budaya

http://abadisantosoganteng.blogspot.com/2011/04/ bangunan-cagar-budaya.html

Riana Afifah | Rabu, 14 Desember 2011 | 12:21 WIB Kompasiana

Undang-undang Nomor 11 Tahun 2010 tentang Cagar Budaya

Peraturan Pemerintah Republik Indonesia Nomor 10

Tahun 1993 tentang Pelaksanaan UU Nomor 5

Tahun 1992 tentang Benda Cagar Budaya 